\title{
GRADUATE EDUCATION PROGRAMS: ITS RELATION TO GRADUATES WORK COMPETENCIES IN THE WORKPLACE
}

\author{
Tarhata S. Guiamalon \\ Assoc. Prof. Dr. Graduate College, Cotabato City State Polytechnic College, Philippines, \\ tarhata_guiamalon@ccspc.edu.ph
}

\begin{abstract}
Improving the quality of graduate education is the Higher Education Institutions' (HEl's) main objective. One way of knowing the quality is determining the graduates' appropriateness and the graduates' work competencies in the workplace. It will help the higher education institutions to get feedback and to know their position in terms of efficiency in providing knowledge to students. It will be used for curriculum development and reform to determine the education curriculum appropriateness to enhance graduates' work performance. The graduates were identified as respondents of the study. These graduates were approached and -asked to participate in the study. They were informed of the nature and purpose of the study. The findings revealed a significant relationship between graduate education courses and the graduates' work competencies in the workplace. This finding implies that if the graduate education courses offering were highly appropriate and its graduates' work competencies tended to be highly competent. It was concluded that the Graduate College of Cotabato City State Polytechnic College (CCSPC) pursued and implements its education programs with pre-requisites courses which were sequentially and logically arranged to meet the needs of its students so that students develop a better understanding of the requirements of the workplace concerning the development of work competencies.
\end{abstract}

Keywords: Graduate Education Program, Appropriateness, Work competencies

\section{INTRODUCTION}

A graduate's weakness and feedback can obtain by a tracer study. This may help the institution in improving its curriculum and instruction and other services for students. Kebedom (2010) opined that conducting graduate tracer study helps the private higher education institutions in determining their status in terms of programs and services efficiency in providing relevant knowledge and skills to students. Zembere and Chinyama (1996) discussed that the main objectives of a tracer study is to investigate the transition process from higher education to the graduates' employment status. Schomburg (2003) opined graduate study to analyze the relationship between higher education and work and work competencies.

Ifeobu (2014) argued that evaluation studies provide useful guides that help make meaningful choices among alternatives and can help educational institutions strengthen and clear some doubts about education programs. On the other hand, Akinbobola \& Bada (2017) also opined that this evaluation involves situation analysis to help institutions determine the students' strengths and weaknesses in or adopt to in improving the student's performance. They further asserted that it would help curriculum planners identify challenging, aspects of the curriculum and select-future learning experiences.

Employability to Yorke (2006) defines it as a concept of a wider range than those of 'core' and 'key' skills". He further argued that employability is a collection of capacities or achievements, which constitute a necessary but not sufficient condition for gaining employment. In addition, Ediagbonya \& Oyadongha (2013) described employment as a group of important skills instilled in each individual to produce a productive workforce. Moreover, according to Robinson (2000) employability skills are the necessary skills needed for 
one to get a job and enable him or her to carry out duties well. According to Harvey et al. (1997) cited by Holden \& Jameson (2002), most employers are looking for proactive graduates who can use higher-level skills that include 'analysis, critique, synthesis, and multi-layered communication for them to facilitate innovative teamwork in catalyzing the transformation of their organization.

The Graduate College of Cotabato City State Polytechnic College (CCSPC) is offering Doctor of Philosophy in Educational Administration, Public Administration, Peace Development; Master of Arts in Education major in Administration and Supervision and English; Master in Public Administration, Plan A, and Plan B; Master of Business Management; Master of Science in Social Work, Master of Science in Information Technology; Master in Information Technology, Master of Science in Islamic Education; Master in Peace Development and Master of Science in Agricultural Extension. The college is envisioned to produce advanced technical professionals; conduct advanced studies research, extension services, and progressive leadership in various fields. Along with this, the college regularly conducts curriculum reviews and enhancement in response to the needs of development for workers in the region and the country. Cognizant of this, it is imperative to determine the extent of the graduate education programs' appropriateness, the level of the graduates' work competencies in the workplace, and its relationship. The study will be used by the CCSPC Graduate College and other stakeholders for curriculum development and reform and to determine the education curriculum appropriateness to enhance its graduates' work performance. Further, this study's findings will also determine the relevance, and weakness of the graduate education program.

\subsection{Related Studies}

Graduate education has already become a trend not only in the Philippines but worldwide. According to Kenny (2008), in her conference paper "Role of postgraduate education in research systems," there is a growing demand for Masters and doctorates related to a specific field of professional activity. Though sometimes referred to as "taught qualifications" that may be undertaken concurrently with actual workplace activity, these involve a certain degree of research for the professors and the students involved. Similarly, Maduka (2014) opined that postgraduate education constitutes a particular investment - whether personal or national - in human capital. The overall objective of postgraduate education is to educate highly skilled citizens and professionals able to address the specific issues of their national contexts as part of -a-wider globalized society. The wealth drawn from people and their expertise and talents forms a base for finding viable solutions to the issues of sustainable human development - particularly in poverty reduction, wide access to health care, education for all, population, good governance, equitable arrangements for globalized economic trends, trade patterns and so on (www.arabianjbmr.com/JPDS index.php).

On the other hand, in Moulding and Hadley (2010) study, the purposes of graduate study in education vary across programs and locations. Often, graduate education programs focus on developing in-service teachers' professionalism and pedagogical skills. However, they may also require a thesis or research project. Further, Moulding and Hadley (2010) stressed that individual students' goals in pursuing graduate degrees in education also vary. Some students seek an understanding of research methods, while others focus more on advanced pedagogical knowledge.

The role of universities in preparing graduates for the workforce is a longstanding and controversial issue (Barnett, 2000a) cited by Nagarajan(_). According to Temmerman (2019), multiple reports point to today's graduates changing jobs up to 10 or even more times during their lifetime. It seems reasonable to assume that there will be some skills (re)training required if these job changes are to successfully occur, especially given the rapidity of new knowledge development

She also emphasized that employers want graduates with both theoretical and practical knowledge and skills. Temmerman (2019) stressed that employers' call for freshly graduated university job hunters to have practical, industry- or professional-related skills. She added that employers want employees who have theoretical knowledge and understanding and hands-on, real-world know-how, and who can 'hit the ground running.' Many university courses now include some work-based learning, but those experiences can be limited in time and breadth of knowledge.

It was reported in "Improving the Postgraduate Student Experience and Employability of Postgraduate Students" of Bond University (2016) that many postgraduate students explain that they are returning to university to change careers or disciplines (i.e., broadening rather than deepening degrees) and therefore may not have relevant experience, skills, goals, and networks in the new domain. It was also reported that despite the identified gaps, postgraduate students (as compared to undergraduate students) tend to be maturely aged, have work experience (if in a different field/discipline). Therefore have further developed transferable skills and a higher degree of complexity of roles and competing demands (e.g., dependents and financial commitments). Furthermore, they tend to have higher developed intellectual or existential goals. 
On the other hand, in the study of Massimi et al. (2016), Italian graduates of the Master's Degree in Nursing reported high levels of satisfaction with the course and high levels of improvement in knowledge and skills in all areas. Still, there was a lower level of implementation of the acquired competencies at work, particularly in management. They also asserted one of the stated outcomes of that Master's degree in Nursing was providing nurses with advanced leadership skills, management skills, and team working skills. Zepeda (2015) opined in her essay, "Graduate students can be strategic about being employable later," graduate programs focus primarily on developing specialized knowledge, advanced critical thinking, and innovative research. Also, graduate students cannot rely solely on their programs to develop more basic skills.

Further, graduate school is a space for learning, practicing, and achieving. It is also an ideal stage to rehearse for future professional performance. Graduate school cannot be approached in the same manner as the undergraduate experience because postgraduate education is directly linked to professional development. Also, Graduate school lays the foundations of a career in a specialized manner, committing students to a discipline, an area, and a focus. She also added that graduate school's advanced education must translate into marketable skills, particularly when the competition is fierce. For this reason, graduate students should work on developing a series of basic skills to improve their chances of employment.

In graduate employability studies of CHERI (2002); HEFCE, (2003); Allen \& van der Velden, (2009); Hemmer, (2011), they concluded that Higher Education Institutions needs to have closer links to the world of work and provide other opportunities to their students to enhance graduate employability. They further observed from their studies relevant in respect to:

- Prior work experience appears to be a highly positive influence on employability, yet, the role of internships and work placements should not be overestimated, as these studies show no significant link between internship taken and the employment rate. Also, combining studies with non-relevant work during the academic year might have a negative effect.

- Employer involvement in course design and delivery is positively associated with graduates' quality of initial employment.

- Involvement in extra-curricular activities and study/work abroad opportunities are also related to successful employment outcomes.

On the other hand, according to Hemmer et al. (2011), in the modern working environment, the graduates have to be able to- work independently and in teams by bringing out and making use of the most vital qualities of the team members. Besides, they asserted that mobilization of human resources/workplaceinterpersonal skills involve the ability to work productively with others, mobilize others' capacities, clearly express one's opinion, and assert one's authority/ leadership skills; interpersonal/teamwork/ network skills. Rothwelland \& Arnold (2005) opined that the individual attributes of employability include the repertoire of knowledge and skills he or she can offer to an employer and their mastery of career management and ability to find a job. They further asserted that employers hire individuals to use such repertoire to perform their core activities, achieve goals, and satisfy stakeholders. Also, Rothwell and Arnold (2005) emphasized that employability's organizational attributes refer to the 'within-organization factors,' such as the current and predicted states of internal labor markets). The general state(s) of the external labor market(s) also affects individual employability, representing the demand for individual knowledge and skills.

\subsection{Statement of the Problem}

This study aims to determine the appropriateness of the graduate education program and the graduates' work competencies in the workplace.

Specifically, this study aims to:

1. What is the extent of the graduate education program's appropriateness offering of the CCSPC Graduate College?

2. What is the level of the work competencies of the graduate students in their work Place?

3. Is there a significant relationship between the graduate education programs offering the graduates' work competencies in the workplace?

\subsection{Hypothesis of the Study}

Ho1. There is no significant relationship between the graduate education programs offering the graduates' work competencies in the workplace. 


\section{METHODOLOGY}

This study utilized the descriptive research design using correlation analysis. It described the appropriateness of the graduate education program and the graduate's work competencies in the workplace. It also established the relationship between the education program's graduate education courses and the graduate's work competencies in the workplace.

The respondents of this study were the seventy-three (73) Graduates of CCSPC Graduate College from school year 2015-2016-2019-2020 and were randomly selected. They were approached and asked to participate in the study, and they were informed of the nature and purpose of the study.

A self-constructed instrument was used to gather the respondents' needed data and information, which described their assessment of the graduate education program's appropriateness to their work performance. The study used the 4-point Likert Scale to avoid the central tendency (de Guzman, 2005). The instrument is composed of two parts. Part 1 elicited the appropriateness of the graduate education courses program of the CCSPC Graduate College, and the part asked the graduates' work competencies. Confidentiality was assured so that to ensure anonymity. No identification was included in the questionnaire.

\section{RESULTS}

\subsection{Results on Appropriateness of Graduate Education Program}

Table 1 shows the result of the appropriateness of the graduate education program. The Table further revealed that the respondents rated "highly appropriate" the items on intensive study of the various methods of research (3.46), analytical study and application of various tools of statistics with computer-assisted instruction (3.54), the study of the structures, systems, processes and dynamics of educational administration, and its role in national development (3.47), the theoretical approaches and strategies to developing a scientific body of knowledge (3.54). This means that the respondents are aware that the graduate programs are appropriate for their approaches, dynamics, and instructions.

Likewise, the respondents also rated highly appropriate the items on theoretical and empirical bases for selected functions of managers; and managing human behavior (3.52), analysis of the country's national development on education and analyzing the problem, evaluating procedure and recommending solution with justification (3.50), administrative processes and policy problems associated with the management financial resources (3.45), analysis of the economic issues and problems related to education (3.54). When asked about it, one of the respondents answered that they had tackled such questions during their classes. They can very well relate to it and help develop their intellectual behavior.

Further, the respondents rated highly appropriate on the items models, theories, and research on finding on the administration of curriculum development, administration of teaching and administration of student affairs (3.54), intensive study of selected legal issues and problems in education. A comprehensive evaluation of research completed and areas needing research in education (3.48), socio-economic, political, and cultural issues and problems relevant to national development and decisions about education (3. 51), analysis of organizational theories, management trends, and processes for and growth. Application of decision-making techniques, training needs analysis, and interventions for management improvement (3.48).

Furthermore, the respondents rated highly appropriate on the items research-based inquiry into critical contemporary issues in the Philippine educational system, culminating in a substantial research paper (3.45), models, theories and empirical basis for capacity building of educational institutions and accreditation practices and assessments for improvement (3.52), theories and research findings on supervisory development and functions; analysis of problems and recommending solution with justification (3.54), an examination of theories and submission of a research paper in leadership and ethics (3.54). During the observation, it was observed that the respondents were listening very well with their professor, who was talking about some Philippine social issues that are related to their subject.

Lastly, the overall mean making was 3.30, which was interpreted as appropriate. This result shows that the graduate programs are appropriate, especially in critiquing, analyzing, and viewing theoretical approaches. Guiamalon \& Hariraya (2020) opined that the faculty's syllabi preparation is a moral responsibility of the faculty. To measures the scope and extent to which ends and means of each course or subject design. They further asserted that syllabi provide direction and guidance to students regarding the scope of the subject matter, methodology, evaluation, and grading system. Alber (2015) cited by Guiamalon \& Hariraya (2020), five effective classroom practices that promote learning: teacher clarity, classroom discussion, feedback, formative assessments, and metacognitive strategies. Further, Guiamalon (2018) highlighted that providing excellent instruction to its students and providing adequate physical resources with ample facilities and 
equipment are necessary.

Table 1. Mean Matrix on the Appropriateness of the Graduate Education Program

Graduate Education Program $\quad$ Mean Description

1. Intensive study of the various methods of research.

3.46

Appropriate

2. Analytical study and application of various tools of statistics with computer -assisted instruction.

Highly Appropriate

3. Study of the structures, systems, processes and dynamics of educational administration, and its role in national development.

Appropriate

4. The theoretical approaches and strategies to developing a scientific body of knowledge.

Highly Appropriate

5. Theoretical and empirical bases for selected functions of managers; and managing human behavior.

Highly Appropriate

6. Analysis of the country's national development on education and analyzing the problem, evaluating procedure and recommending solution with justification.

Highly Appropriate

7. Administrative processes and policy problems associated with the management of financial resources.3.45

Appropriate

8. Overview of the national economy. Analysis of the economic issues and problems related to education.

Highly Appropriate

9. Models, theories and research on findings on the administration of curriculum development, administration of teaching and administration of student affairs.

Highly Appropriate

10. Intensive study of selected legal issues and problems in education. Comprehensive evaluation of research completed and areas needing research in education.

Appropriate

11. Socio-economic, political and cultural issues and problems relevant to national development and decisions in relation to education

12. Analysis of organizational theories, management trends and processes for and growth. Application of decision- making techniques; training needs analysis and interventions for management improvement. 
13. Research-based inquiry into critical contemporary

issues in the Philippine educational system,

culminating in a substantial research paper.

Appropriate

14. Models, theories and empirical basis for capability

building of educational institutions and accreditation

practices and assessments for improvement.

Highly Appropriate

15. Theories and research findings on supervisory

development and functions; analysis of problems

and recommending solution with justification.

3.54 Highly Appropriate

16. Examination of theories and submission

of a research paper in leadership and ethics.

$3.54 \quad$ Highly Appropriate

\begin{tabular}{|c|c|c|}
\hline Grand Mean & 3.30 & Appropriate \\
\hline
\end{tabular}

$$
\begin{aligned}
& 3.50 \text { - 4.00- Highly Appropriate } \\
& 2.50 \text { - 3.49- Appropriate; } \\
& 1.50 \text { - 2.49- Less Appropriate } \\
& 1.00 \text { - 1.49- Least Appropriate }
\end{aligned}
$$

\subsection{Results on Work Competencies}

Table 2 shows the result on the extent of graduates' work competencies. The Table further revealed that the respondents rated "highly competent" the items on conceptual thinking (3.52), organizationall awareness (3.49), technical expertise (3.50), and decision making (3.52). This means that the respondents were engaged in developing, and implementing strategies and policies that encourage reflection, leading to refinement and growth. These results corroborate with Abimbola \& Abolade (2010) notion that the most important part of the learning experience is through practical work, which gives the student some practical scientific experiences that are needed in everyday life. And these experiences were applied by the graduates at their workplace.

Likewise, the respondents also rated highly competent the items on oral and written communication (3.50), personal planning \& organizational skills (3.50), problem-solving (3.49), community awareness, engagement and advocacy (3.52), and facilitating collaborative relationships (3.48). When asked about it, the respondent answered that to have a smooth sailing relationship with his students and co-teachers, he tends to approach them and communicate with them regularly. These results imply that the respondents show a willingness to work as part of a group to address and implement resolutions to needs and/or challenges. Lastly, the overall mean rating was 3.50 , which was interpreted as highly competent. The finding shows that the competency is very laudable as it reaches a very competent rating. Harvey (2001) and Crossman\& Clarke (2010) asserted that employability could not be purely individual or institutional achievement but an outcome of the joint's initiatives and involvement of all stakeholders. These stakeholders are students, graduates, school administrators, policymakers, and representatives of various related associations, organizations, and government agencies.

Table 2. Mean Matrix on the Graduates Work Competencies

Work Competencies Mean Description
1. Conceptual Thinking
3.52 Highly Competent
2. Organizational Awareness
3.49 Competent
3. Technical expertise.
3.50 Highly Competent 

4. Decision Making.
3.52 Highly Competent
5. Oral and written communication.
3.50 Highly Competent
6. Personal planning and organizational skills.
3.50 Highly Competent
7. Problem solving
3.49 Competent
8. Community awareness, engagement, and advocacy.
3.52 Highly Competent
9. Facilitating collaborative relationships.
3.48 Competent

\section{Grand Mean}

3.50 Highly Competent

Legend:

$$
\begin{aligned}
& 3.50-4.00 \text { - Highly Competent } \\
& 2.50-3.49 \text { - Competent } \\
& 1.50-2.49 \text { - Less Competent } \\
& 1.00-1.49 \text { - Least Competent }
\end{aligned}
$$

\subsection{Results on the Relationship}

Table 3 presents the correlation between the graduate education courses and the graduates' work competencies in the workplace.

Based on the Table, the graduate education courses and the graduates' work competencies in the workplace had significant relationships as shown by their correlation coefficient of .463 and significance probability $=.000$, which was significant at .01 . The null hypothesis of no significant relationship between the graduate education courses and the graduates' work competencies in the workplace was rejected. This meant that there was a significant relationship between the graduate education courses and the graduates' work competencies in the workplace. This finding implies that if the graduate education courses offering were highly appropriate, its graduates' work competencies tended to be highly competent.

Table 3.Correlational Matrix Between the Graduate Education Programs and Graduates Work Competencies in the Work Place

Work Competencies

Education Programs $\quad .463^{* *}$

.000

${ }^{* *}$ Correlation is Significant at 0.01 level (2-tailed)

\section{CONCLUSION}

The CCSPC Graduate College pursued and implemented its education programs with pre-requisites courses that were sequentially and logically arranged to meet its students' needs. Students develop a better understanding of workplace requirements with respect to the development of work competencies.

\section{RECOMMENDATION}

The following are strongly recommended based on the findings of this study:

1. The Graduate college may develop a program that will further develop and enable its students to develop research skills, practical and planning skills, time management skills, thinking and analytical skills, and reflective and evaluative skills.

2. Benchmarking on Graduate College management best practices of international universities may be conducted.

3. The teachers' different instructional processes, methodologies, and learning opportunities may be 
revisited to sustain quality instruction.

4. The college may design a scheme to increase faculty involvement in conducting, presenting, and publication of research.

5. Linkages with Universities, Non-Government Organizations, and Government agencies should be strengthening to support and provide assistance for the faculty and students and the operation of the graduate college.

\section{REFERENCE LIST}

Abimbola,I.O.\&AboladeA.O.(2010).Fundamental principles and practice of instruction, Ilorin: University of llorin Press

Akinbobola, A.O .,\& Bada, A.A.(2017). Creative aching of physics. Oyekan, S.O., Akinbobola, A.O., \& Adebile, R.F.(Eds), A compendium of teaching methods. Patrick AdePrints (Nig.).Ltd., Ondo.pp.221-260.

Allen, J. (ed.), Velden, R. K. W. (ed.), Svetlik, I., Pavlin, S., et al. (2009): Competencies and early labor market careers of higher education graduates: report on the large-scale graduate survey. [S. I.]: HEGESCO: the University of Ljubljana, Faculty of Social Sciences, Dec. 2009

CHERI (2002). Access to what: analysis of factors determining graduate employability. A report to the HEFCE by the Centre for Higher Education Research and Information(CHERI)

Crossman, J.E., \& Clarke, M. (2010). International experience and graduate employability: stakeholder perceptions on the connection. Higher Education (2010) 59:599-613

Ediagbonya, K \& Oyadongha, DJ 2013, Survey on Employability Skills among Post Graduate Students of Business Education in Edo State. European Journal of Educational Studies 5(2).

Guiamalon, T., 2018. Baseline Study on Improved Instructional Programs of CCSPC College of Education.

Availablefrom: https://www.researchgate.net/publication/344597396 Baseline Study on Improved Instructional Programs of CCSPC College of Educat ion [accessed Dec 152020 ].

Guiamalon, T., Hariraya, P. (2020). (PDF) THE K-12 SENIOR HIGH SCHOOL PROGRAM: THE CASE OF LABORATORY HIGH SCHOOL, COTABATO CITY STATE POLYTECHNIC COLLEGE, SOUTH CENTRAL MINDANAO, PHILIPPINES. Available from:https://www.researchgate.net/publication/344596803 THE K12 SENIOR HIGH SCHOOL PR OGRAML THE CASE OF LABORATORY HIGH SCHOOL COTABATO CITY STATE POLYTEC HNIC COLLEGE SOUTH CENTRAL MINDANAO PHILIPPINES [accessed Dec 15 2020].

Harvey, L. (2001). Defining and Measuring Employability. Quality in Higher Education, Vol. 7, 2, 2001

Hemmer, S., Pommer, S., Knabl, J., Calmand, J., Hallier, P., \& Bouder, A. (2011). Erasmus Mundus: Clustering Erasmus Mundus masters courses and attractiveness projects: Lot 2: Employability. Survey results.

HEFCE (2003). How Much Does Higher Education Enhance the Employability of Graduates? Graduate employability study. Summary of the report to the Higher Education Funding Council for England (HEFCE)

Ifeobu, H. N. (2014). Evaluation of the implementation of the national curriculum for secondary school biology in Anambra State. Department of Education, University of Nigeria, Nsukka.

Kebedom, Negus (2010) Sheba University College Graduates Tracer Study Sheba University College: Quality Assurance Curriculum and Research Office. http://www.suc.edu.et/TracerStudy.html. Retrieved 11/27/2020

Massimi et al. (2016). Are knowledge and skills acquired during the Master's Degree in Nursing actually put into practice? A pilot study in Italy. Available from:

https://www.researchgate.net/publication/301544812 Are knowledge and skills acquired during th 
e Master Degree in Nursing actually put into practice A pilot study in Italy [accessed Nov 02 2020].

Kenny, M-L (2008). Role of postgraduate education in research systems conference:

Trends and Issues in Postgraduate Education: Challenges for Research, Dublin, 2008. https://unesdoc.unesco.org/ark:/48223/pf0000159388. [accessed Nov 02 2020].

Maduka, C-E (2014). Postgraduate Education and Human Resources Development in Nigeria. Journal of

Policy and Development Studies, Vol. 9, No. November 1, 2014. ISSN: 157-9385 www.arabianjbmr.com/JPDS index.php. [accessed Nov 02 2020].

Maulding, L. \& Hadley, K. (2010). Graduate Students' Understanding of Educational Research in a Master of Education Program New Horizons in Education, Vol.58, No.1, May 2010.

https://files.eric.ed.gov/fulltext/EJ893711.pdf. [accessed Nov 02 2020].

Nagarajan, S. \& Edwards, J. (_).The Role of Universities, Employers, Graduates, and Professional

Associations in the Development of Professional Skills of New Graduates. https://jpaap.napier.ac.uk/index.php/JPAAP/article/view/137/html

Rothwell, A., Arnold J. (2007). Self-perceived employability: Development and validation of a scale.Personnel Review, 36(1):23-41. DOl:10.110800483480710716704

Schomburg, H. (2003). Graduate tracer studies at the Kassel center. Retrieved from http://www.unikassel.de/wz1 on September 28, 2013.

Temmerman, N. (2019). When A Degree Just Isn't Enough, Also Offer Upskilling.

https://www.universityworldnews.com/post.php?story=20190304094729650

Yorke, M 2006, Employability in Higher Education: What It is - What It is Not. New York: Higher Education Academy.

Zembere S.N. and Chinyama N.P.M (1996) "The University of Malawi Graduate Tracer Study." University of Malawi. Blantyre. http://www.aau.org/studyprogram/notpub/ZEMBERE.pdf.

Zepeda, K. (2015). Graduate Students Can Be Strategic About Being Employable Later. An Essay.

https://www.insidehighered.com/advice/2015/01/05/essay-five-professional-skills-graduate-students-learn (2016). Improving the Postgraduate Student Experience and Employability of Postgraduate

Students. An Overview of National Research Findings and Preliminary Resource Guide. Bond University. https://www.acgr.edu.au/wp-content/uploads/2018/09//mproving-the-Postgraduate-StudentExperience-and-Employability-of-Postgraduate-Students.pdf. [accessed Nov 02 2020]. 